\title{
Uji Validitas dan Reliabilitas South African Career Interest Inventory Short
}

\author{
Natalia Juliana, William Gunawan \\ Fakultas Psikologi Universitas Kristen Krida Wacana \\ email:william.gunawan@ukrida.ac.id
}

\begin{abstract}
Abstrak
Artikel INFO

Diterima:08 Juni 2021

Direvisi 16 Agustus 2021

Disetujui: 23 September 2021

DOI:

http://dx.doi.org/10.24014/ jp.v14i2.12676

Penelitian ini bertujuan untuk menguji validitas dan reliabilitas alat ukur minat karier South African Career Interest Inventory Short Form (Morgan \& Bruin,2019) versi bahasa Indonesia. Subjek pada penelitian ini melibatkan 332 orang remaja yang ada pada jenjang pendidikan SMA (Sekolah Menengah Atas) dan SMK (Sekolah Menengah Kejuruan) pada kelas 10,11,12 di Indonesia. Subjek merupakan remaja berusia 1518 tahun. Teknik sampling yang digunakan adalah aksidental sampling. Penelitian ini menggunakan menggunakan uji validitas konvergen dan reliabilitas internal consistency. Validitas konvergen digunkan untuk menguji korelasi RIASEC skor SACII-SR dengan Onet Interest Profiler. Hasil penelitian menunjukkan bahwa SACII-SR valid dan memiliki reliabilitas yang baik. SACII-SR dapat dimanfaatkan dan dapat berkontribusi dalam proses pengukuran minat karier yang relevan dengan konteks di Indonesia. Selain itu, SACII-SR dapat digunakan untuk keperluan seperti konseling karier atau pencarian minat karier itu sendiri.
\end{abstract}

Kata kunci : Alat ukur minat karier , minat karier, reliabilitas, validitas

\section{Validity and Reliability South African Career Interest Inventory Short}

\begin{abstract}
This research aimed to test the validity and reliability of the Indonesian version of the South African Career Interest Inventory Short Form (SACII-SR, Morgan \& Bruin,2019). 332 high school and vocational school students from grades 10 to 12 participated in this study. Subjects are teenagers aged 15-18 years. The sampling technique used was accidental sampling. This study uses convergent validity and internal consistency reliability tests. The convergent validity was assessed to correlate RIASEC score of SACII-SR with Onet Interest Profiler.The results showed that SACII-SR is valid and has good reliability. SACII-SR can be utilized and contributed as relevant career interest measurements in Indonesia. Besides, SACII-SR occurs as utilization of career counseling and identify individual interest in future career direction.
\end{abstract}

Keywords : Measuring Tool of Career Interest, Career Interest,, reliability, validity

\section{Pendahuluan}

Karier merupakan aspek penting dalam kehidupan manusia. Menurut Super, Thompson, Lindeman, Jordan \& Myers (1981) karier merupakan proses yang terjadi sepanjang kehidupan manusia. Menurut Ekaningrum (dalam Sisca \& Gunawan, 2015) karier digunakan untuk menjelaskan peran seseorang dalam pekerjaannya. karier adalah proses penting di kehidupan manusia yang tidak hanya berkutat dalam pekerjaan namun merupakan proses yang terjadi terus di sepanjang kehidupan seseorang.
Sharf mengatakan, (dalam Sisca \& Gunawan, 2015) remaja usia 15-18 tahun merupakan masa penting untuk menentukan karier yang dibuatnya. Bagi remaja Indonesia, pengambilan keputusan karier akan dilakukan dengan memilih jurusan antara IPA dan IPS. Setelah lulus SMA, bagi yang ingin melanjutkan ke perguruan tinggi negeri akan dihadapkan kembali dengan pemilihan jurusan. Pilihan jurusan yang dilakukan remaja berkaitan dengan perkembangan kariernya. 
Super (1975) menjelaskan usia 15 sampai 24 tahun merupakan tahap perkembangan eksplorasi dimana individu mulai menilai diri dan mengeksplorasi pekerjaan yang mungkin ditekuni nantinya. Pada usia 15 dan 17 tahun seharusnya seorang remaja sudah mengetahui kebutuhan, minat, nilai, dan kesempatan yang dimiliki. Remaja dapat melakukannya dengan diskusi, kursus atau bekerja. Hal ini menunjukkan idealnya remaja sudah memiliki kesadaran terhadap karier dan bisa menyusun perencanaan karier.

Pada kenyataannya menurut Susantoputri dan Gunawan (2014) menjelaskan bahwa sebagian remaja tidak mampu membuat pilihan dengan tepat dan sesuai tahapan kariernya. Menurut Akmal, Arlinkasar, dan Kumalasari (2017) sebagian remaja Indonesia mengalami kesulitan dalam memilih jurusan. Hal ini juga ditemukan dalam penelitian youthmanual (2019) pada 400.000 siswa dan mahasiswa menemukan bahwa terdapat $92 \%$ siswa SMA dan SMK merasa bingung dan tidak tahu akan menjadi apa ke depannya.

Beberapa faktor penyebab dari permasalahan pengambilan keputusan karier adalah siswa belum tahu minatnya akan program studi tertentu, pilihan program studi yang diminati siswa berbeda dengan keinginan orang tua, siswa belum tahu prospek karier dari program studi yang diminati, dan siswa merasa belum memiliki kemampuan yang memadai sehingga merasa tidak yakin dan tidak percaya diri untuk mendaftar di program studi yang diminati (Ardiyanti \& Alsa, 2015). Selanjutnya dari penelitian yang dilakukan Ardiyanti dan Alsa (2015) diketahui bahwa kesulitan siswa terhadap pemilihan jurusan yang akan diambil yaitu siswa belum mengetahui minatnya. Tentunya pemilihan jurusan yang dilakukan tanpa mengetahui minat diri dapat menghasilkan ketidaksesuaian pilihan dengan minat diri yang sebenarnya, setelah kegiatan perkuliahan dijalani baru akan merasakan kesulitan atau ketidaksesuaian minat dengan jurusan.

Pengetahuan mengenai minat yang dimiliki menjadi penting untuk pemilihan jurusan dan karier selama seumur hidup. Minat merupakan salah satu faktor penting dalam pengambilan keputusan karier remaja. Berdasarkan survei student career research foundation (2017) menemukan bahwa minat dan pengalaman memberikan motivasi tertinggi dalam menentukan kariernya dengan persentase sebesar $71 \%$. Menurut Holland (dalam Kumaidi, Farida \& dan Haq , 2017) bahwa pengenalan minat dan karakteristik individu akan dapat memprediksikan pekerjaan yang tepat dan memuaskan bagi individu. Menurut Süerdem \& Erkök (2016) seorang individu yang minat kariernya cocok dengan lingkungan kerjanya akan lebih termotivasi untuk mendapatkan pengetahuan dan skill yang sesuai, hal ini memungkinkan individu dapat melakukan pekerjaannya lebih baik daripada yang tidak sesuai. Hal ini menunjukkan bahwa minat merupakan suatu aspek yang penting dalam karier.

Walgito (dalam Syamsudin, Hakim, \& Atmasari, 2019) menjelaskan minat sebagai faktor pendorong yang menjadikan seseorang lebih giat dan memanfaatkan setiap peluang yang ada dengan mengoptimalkan potensi yang tersedia, minat juga merupakan rasa ketertarikan terhadap sesuatu tanpa paksaan. Melihat minat yang merupakan faktor pendorong dan karier yang merupakan perkembangan peran seseorang dalam hidup, maka dapat disimpulkan bahwa minat karier berhubungan dengan menggambarkan orientasi kejuruan seseorang terhadap aktivitas kerja dan lingkungan pekerjaan tertentu (Holland, 1985).

Holland (1985) menjelaskan bahwa alat ukur minat dapat digunakan untuk mengukur seberapa banyak individu memiliki karakteristik yang dapat diidentifikasi kedalam tipe kepribadian. Holland menjelaskan bahwa kepribadian dapat dideskripsikan kedalam 
enam tipe. Lingkungan minat kerja juga dapat dideskripsikan sebagai kombinasi dari enam tipe. Orang-orang dengan karakteristik dengan tipe tertentu akan tertarik dengan lingkungan yang memiliki tipe yang sama.

Holland (1985) menyatakan bahwa kepribadian dan lingkungan minat kerja terbagi dalam enam dimensi yaitu Realistic $(R)$, Investigative (I), Artistic (A), Social (S), Enterprising (E), dan Conventional (C). Realistic adalah tipe yang senang bekerja dengan alat, objek mesin atau hewan. Investigative adalah tipe yang menyukai kegiatan yang melibatkan ilmu biologis dan fisika. Artistic adalah tipe lebih menyukai kegiatan-kegiatan kreatif daripada rutinitas. Social adalah menyukai kegiatan yang melibatkan pemberian informasi, mengajar, dan menolong orang lain. Enterprising adalah menyukai kegiatan yang memungkinkan untuk memimpin atau memengaruhi orang lain. Conventional adalah menyukai kegiatan memungkinkan pengorganisasian informasi secara jelas dan tertib.

Sebagai upaya untuk meminimalisasi pemilihan karier yang tidak sesuai dengan minat, maka pengembangan alat ukur minat menjadi suatu hal yang penting dan urgen untuk dilakukan, hal ini didukung oleh Cummings dan Worley (2009). Menurut Gati dan Peretz (dalam Ratri, 2016) menjelaskan bahwa asesmen minat karier perlu dilakukan untuk mempermudah membuat keputusan dalam pemilihan karier. Menurut Cummings dan Worley (dalam Ratri, 2016) juga menjelaskan bahwa proses diagnosis terhadap minat karier seseorang perlu untuk dilakukan sebagai proses awal pada intervensi perencanaan dan pengembangan karier. Hal ini menunjukkan bahwa asesmen minat perlu dilakukan dalam perencanaan maupun keputusan karier .

Alat ukur minat pada saat ini sudah banyak ditemukan dan dikembangkan. Menurut Yudiana, Reswara dan Wiyono
(2019) alat ukur minat yang digunakan di indonesia diantaranya yaitu Kuder Preference Record Form C (Kuder, 1948), The Rothwell Miller Interest Blank (RMIB) (Rothwell, 1947). Menurut Kennelly, Sargent dan Reardon (2018) di Indonesia juga tersedia SelfDirected Search (SDS) $4^{\text {th }}$ edition form $R$. Menurut Hansen (dalam Goldstein, Allen \& Delluca,2019) terdapat beberapa alat ukur minat yang banyak digunakan saat ini yaitu Campbell Interest and Skill Survey (Campbell, 1995), Self Directed Search (Holland, 1971,1979, 1985, 1994; Holland \& Messer, 2013b), Strong Interest Inventory (Consulting Psychologists Press, 2004, 2012; Hansen \& Campbell, 1985), dan Career Assessment Inventory (Johansson, 1975,1986). Dari beberapa jenis alat ukur minat yang sudah disebutkan dapat disimpulkan bahwa saat ini sudah banyak alat minat yang dapat digunakan.

Di antara alat ukur yang ada, SDS dengan dasar teori RIASEC Holland merupakan alat tes minat yang paling banyak diteliti. Kennelly et al. (2018) menyatakan bahwa SDS sudah diterjemahkan atau dipublikasikan dalam 46 bahasa yang berbeda di seluruh dunia. Kennelly et al. (2018) menambahkan bahwa terdapat 4,023 kutipan referensi mengenai RIASEC Holland berdasarkan 5 kategori. Kategori pertama pengaplikasian teori RIASEC terhadap karier sebanyak 1,487 kutipan referensi , kategori kedua pengaplikasian teori RIASEC terhadap populasi spesifik sebanyak 896 kutipan referensi, ketiga validitas dan reliabilitas teori RIASEC sebanyak 767 kutipan referensi, keempat berdasarkan populasi beragam sebanyak 648 kutipan referensi, dan kelima secara alat tes seperti SDS sebanyak 225 alat tes. Banyaknya kutipan referensi menunjukkan bahwa SDS dan tipe kepribadian kejuruan RIASEC Holland sudah banyak diuji dan banyak pengaplikasiannya. SDS dan teori RIASEC juga sudah banyak diteliti di US maupun secara Internasional. 
Walaupun sudah banyak digunakan, alat ukur SDS mendapatkan banyak kritikan. Terdapat beberapa kekurangan pada SDS yang tersedia di Indonesia yaitu beberapa pekerjaan yang terdapat di masa kini juga belum termasuk ke dalam alat tes SDS, misalnya pekerjaan sebagai Youtuber, aktuaria, dan lainnya. Hal lain yang perlu dipertimbangkan adalah banyaknya jumlah aitem yang ada dalam SDS Form $R$, yaitu sejumlah 360 aitem, yang memerlukan waktu yang cukup banyak untuk mengerjakannya.

Alat ukur minat dalam bentuk short form sangat dibutuhkan saat ini. Menurut Donellan (dalam Morgan \& Bruin, 2019) menjelaskan bahwa alat ukur dalam bentuk short form akan lebih membantu memfasilitasi penelitian dibandingkan alat ukur minat yang memiliki aitem terlalu banyak. Alat ukur yang memiliki item terlalu banyak bisa menyebabkan responden merasa bosan yang akhirnya respon jawaban menjadi acak atau tidak sesuai dengan pilihannya, selain itu responden cenderung tidak mau untuk berpartisipasi terhadap penelitian karena memakan waktu yang cukup lama. Morgan dan Bruin (2019) menemukan bahwa beberapa partisipan merasa ragu untuk berpartisipasi dalam penelitian minat kejuruannya ketika diminta menyelesaikan beberapa kuesioner yang panjang.

Morgan dan Bruin (2019) telah mengembangkan sebuah alat ukur minat karier dalam bentuk short form berdasarkan tipe kepribadian kejuruan RIASEC Holland (1997) yaitu South African Interest Inventory Short form. Morgan dan Bruin (2019) menjelaskan bahwa SACII-SR merupakan alat ukur minat yang mengoperasionalkan dimensi minat karier Holland (1985) yang terdiri dari realistic, investigative, artistic, social, enterprising dan conventional. Penelitian ini akan melakukan uji validitas dan reliabilitas pada tes minat South African Interest Inventory Short form. Alat ukur short form ini memiliki jumlah aitem sejumlah 30 item, jauh lebih sedikit dari SDS versi $\mathrm{R}$.
Peneliti merasa tertarik menerjemahkan South African Career Interest Inventory Short form (SACII-SR) yang disusun oleh Morgan dan Bruin (2019). SACII-SR merupakan short form dari alat ukur sebelumnya yaitu SACII. Berdasarkan hasil penelitian sebelumnya Morgan dan Bruin (2019) SACII-SR dan SACII setiap dimensinya memiliki korelasi yang kuat $(R=0,92, I=0,90, A=0,89, S=0,87, E=$ 0,87, $C=0,90)$. Reliabilitas koefisien tiap dimensi dalam SACII-SR berkisar dari 0,80 sampai 0,89 yang artinya memiliki reliabilitas kuat. Koefisien reliabilitas yang diperoleh dalam penelitian ini juga menunjukkan bahwa SACII-SR dapat dibandingkan secara baik dengan alat ukur minat short form lainnya seperti O*NET interest profiler. Contohnya pada $O^{*} N E T$ interest profiler menunjukkan hasil koefisien reliabilitas dari 0.70 sampai 0,75 dan pada penelitian kedua menunjukkan hasil 0.74 sampai 0,81 . Hasil ini mendukung penggunaan aitem secara reliabilitas pada SACII dalam mengukur enam dimensi minat karier Holland. Sehingga dapat menunjukkan bahwa angka koefisien antar Analisa tanggapan responden terhadap 30 aitem SACII-SR menunjukkan reliabilitas yang memuaskan dan sesuai dengan teori RIASEC.

Peneliti belum menemukan adaptasi maupun uji validitas dan reliabilitas South African Career interest Inventory Short Form di Indonesia. Berdasarkan pertimbanganpertimbangan di atas, maka peneliti ingin mengetahui apakah alat ukur South African Career Interest Inventory Short form versi Indonesia sudah valid dan reliabel?

\section{Metode}

\section{Partisipan}

Penelitian ini merupakan penelitian kuantitatif deskriptif, karena bertujuan untuk menguji validitas dan reliabilitas alat ukur. Alat ukur yang diuji disebut South African Career Interest Inventory short form. Pengujian validitas menggunakan validitas tampang dan validitas konvergen. Sampel 
dari penelitian ini adalah remaja madya berusia 15-18 tahun yang duduk di bangku SMA dan SMK di Indonesia. Jumlah subjek pada penelitian ini sebanyak 332 partisipan. Pengambilan sampel pada penelitian ini menggunakan teknik sampling aksidental, dimana penentuan sampel berdasarkan siapa saja yang kebetulan bertemu dengan peneliti dan cocok dijadikan sumber data.

\section{Pengukuran}

Pengumpulan data pada penelitian ini menggunakan alat ukur SACII-SR (Morgan \& Bruin, 2019) dan ONET* Interest Profiler (Rounds, Su, Lewis, \& Rivkin, 2010). Ada 6 dimensi dalam alat ukur SACII-SR yaitu realistik, investigative, artistik, sosial, enterprising, dan konvensional. Alat ukur ini memuat 30 aitem yang di dalam setiap dimensinya terdapat 5 aitem. Pada Onet ${ }^{*}$ IPSF terdapat 6 dimensi yaitu realistik, investigative, artistik, sosial, enterprising, dan konvensional. Alat ukur ini memuat 60 aitem yang di dalam setiap dimensi terdapat 10 aitem. Masing-masing aitem diresponi / dengan memilih skala Likert dari angka satu yang artinya sangat tidak setuju, sampai lima yang artinya sangat setuju.

Pengujian reliabilitas alat ukur teknik internal consistency Alpha's Cronbach. Metode pengujian validitas pada penelitian ini adalah validitas konvergen dengan karena peneliti ingin melihat sejauh mana alat ukur SACII-SR dapat mengungkapkan suatu trait yang hendak diukur. Pada analisa faktor akan menggunakan metode korelasi antar item karena peneliti ingin menguji keselarasan fungsi aitem dengan fungsi ukur tes.

\section{Analisis Data}

Tahap Pada tahap persiapan penelitian, peneliti memilih dan mempersiapkan alat ukur South African Career Interest Inventory Short Form yang terdiri dari 30 aitem yang masih berbahasa Inggris, untuk diterjemahkan ke dalam Bahasa Indonesia. Tahap penerjemahan bahasa terdiri dari forward- backward translation. Forward Translation menggunakan jasa badan penerjemah yang tersumpah. Selain alat ukur SACII-SR, peneliti juga melakukan forward backward translations terhadap alat ukur $O^{*} N E T$ interest profiler short form yang akan digunakan peneliti untuk melakukan pengujian validitas konvergen. Setelah forward-backward translations selesai, peneliti melakukan expert review, yaitu hasil penerjemahan SACII-SR dan ONET* IPSF diperiksa oleh pembimbing peneliti untuk mengoreksi kata dan kalimat sesuai yang telah diterjemahkan. Ada perubahan kata dalam alat ukur ONET* IPSF pada aitem nomor 42 dari menampilkan tap dance menjadi melakukan tarian. Setelah kedua alat ukur yang akan digunakan siap untuk disebar, peneliti menggunakan survey monkey sebagai platform online survey.

Peneliti mulai menyebar kuesioner penelitian yaitu kedua alat ukur tersebut. Penyebaran kuesioner diperluas melalui media sosial seperti Instagram, Line, dan Whatsapp dengan memberikan link agar dapat terhubung dengan survey monkey dan melakukan pengisian kuesioner. Setelah tanggal yang telah ditetapkan peneliti, kuesioner berhenti disebar. Setelah semua data terkumpul, peneliti mulai mempersiapkan semua data yang didapatkan untuk masuk kepada tahap analisa data dengan menggunakan perangkat lunak analisa data. Peneliti kemudian menyusun bab empat dan lima setelah tahap analisa data selesai dilakukan.

\section{Hasil}

Berdasarkan hasil penelitian didapatkan 332 partisipan. Partisipan memiliki rentang usia 16-18 tahun dengan mayoritas berusia 18 tahun. Partisipan perempuan sebanyak 259 partisipan $(78,0 \%)$ dan laki-laki sebanyak 73 partisipan $(22,0 \%)$. Partisipan yang saat ini menempuh pendidikan di SMA sebanyak 218 partisipan (65,6\%) dan SMK 114 partisipan $(34,4 \%)$. Pada partisipan terbagi dari tiga 
beberapa IPA sebanyak 156 partisipan $(46,9 \%)$, IPS terdapat 58 partisipan $(17,5 \%)$ dan bahasa sebanyak 4 partisipan $(1,8 \%)$, jurusan pada SMK terdiri beberapa yang mayoritasnya adalah akuntansi, teknik, dan keperawatan sebanyak 118 partisipan $(35,5 \%)$.

Uji normalitas dalam penelitian ini menggunakan metode skewness dan kurtosis dan P-P plot karena ketika ukuran sampel

Tabel 1 Hasil uji normalitas skewness berjumlah besar (> 100), bentuk distribusi harus diperiksa secara grafis karena dengan ukuran sampel yang besar hipotesis nol normalitas biasanya akan ditolak (Price, 2017). Pengujian normalitas skewness dan kurtosis pada SACII-SR didapatkan hasil skewness dari -0,443 sampai dengan 0,895, dan kurtosis sebesar - 0,164 sampai 0,848. Berdasarkan data skewness dan kurtosis beserta P-P plot, menunjukkan bahwa data berdistribusi normal.

\begin{tabular}{lll}
\hline Metode & Dimensi & Hasil uji normalitas \\
\hline Skewness & Realistic & $-0,067$ \\
& Investigative & $-0,443$ \\
Artistic & $-0,474$ \\
Social & $-0,717$ \\
Enterprising & $-0,895$ \\
Conventional & $-0,507$ \\
\hline
\end{tabular}

Tabel 2 Hasil uji normalitas kurtosis

\begin{tabular}{lll}
\hline Metode & Dimensi & Hasil uji normalitas \\
\hline Kurtosis & Realistic & $-0,740$ \\
& Investigative & 0,367 \\
& Artistic & 0,075 \\
Social & 0,328 \\
& Enterprising & 0,848 \\
& Conventional & $-0,164$ \\
\hline
\end{tabular}

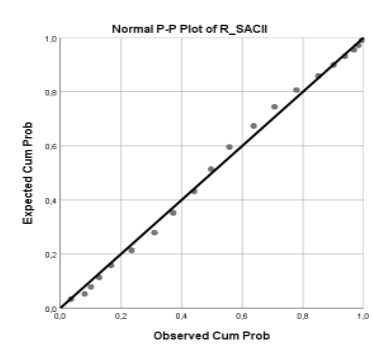

Realistik

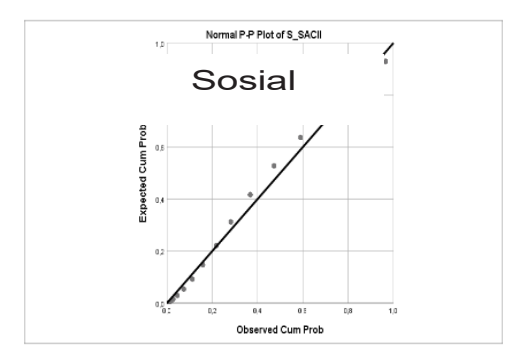

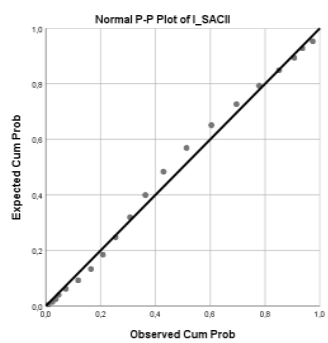

Investigative
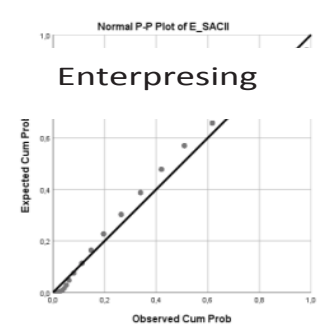

Gambar 1. Grafik hasil uji P-PLOT

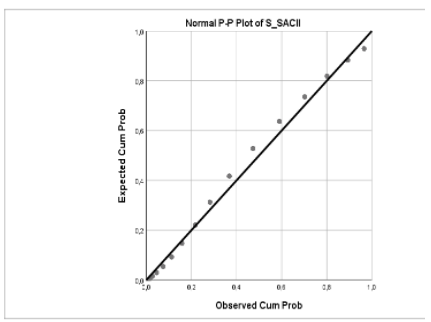

Artistik

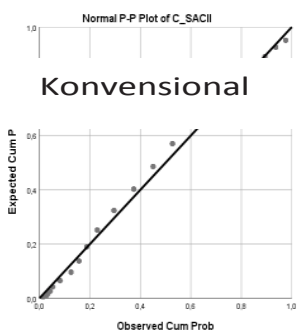


Pengujian item total correlation dilakukan

Uji item total correlation SACII-SR didapatkan untuk mengukur keselarasan fungsi aitem dengan fungsi ukur tes (Azwar, 2019). Suatu butir pertanyaan dikatakan valid jika nilai r-hitung yang merupakan nilai dari Corrected item-Total Correlation > 0,30 (Sugiyono,2017). hasil dari 0,486 sampai dengan 0,805. Hasil ini menunjukkan alat ukur SACII-SR pada setiap dimensinya memiliki item yang valid dengan daya beda yang baik dan signifikan.

Tabel 3 Korelasi aitem total realistik

\begin{tabular}{|c|c|c|}
\hline ID & $\begin{array}{l}\text { Corected item- } \\
\text { total corelations }\end{array}$ & Keterangan \\
\hline SACII_1 & 0,744 & $\begin{array}{l}\text { Aitem valid memiliki daya beda yang baik dan } \\
\text { signifikan }\end{array}$ \\
\hline SACII-_2 & 0,805 & $\begin{array}{l}\text { Aitem valid memiliki daya beda yang baik dan } \\
\text { signifikan }\end{array}$ \\
\hline SACII_3 & 0,726 & $\begin{array}{l}\text { Aitem valid memiliki daya beda yang baik dan } \\
\text { signifikan }\end{array}$ \\
\hline SACII_4 & 0,769 & $\begin{array}{l}\text { Aitem valid memiliki daya beda yang baik dan } \\
\text { signifikan }\end{array}$ \\
\hline SACII_5 & 0,733 & $\begin{array}{l}\text { Aitem valid memiliki daya beda yang baik dan } \\
\text { signifikan }\end{array}$ \\
\hline
\end{tabular}

Tabel 4 Korelasi aitem total investigative

\begin{tabular}{|c|c|c|}
\hline ID & $\begin{array}{l}\text { Corected item- } \\
\text { total corelations }\end{array}$ & Keterangan \\
\hline SACII_6 & 0,666 & $\begin{array}{l}\text { Aitem valid memiliki daya beda yang baik dan } \\
\text { signifikan }\end{array}$ \\
\hline SACII_7 & 0,723 & $\begin{array}{l}\text { Aitem valid memiliki daya beda yang baik dan } \\
\text { signifikan }\end{array}$ \\
\hline SACII_8 & 0,632 & $\begin{array}{l}\text { Aitem valid memiliki daya beda yang baik dan } \\
\text { signifikan }\end{array}$ \\
\hline SACII_9 & 0,726 & $\begin{array}{l}\text { Aitem valid memiliki daya beda yang baik dan } \\
\text { signifikan }\end{array}$ \\
\hline SACII_10 & 0,730 & $\begin{array}{l}\text { Aitem valid memiliki daya beda yang baik dan } \\
\text { signifikan }\end{array}$ \\
\hline
\end{tabular}

Tabel 5 Korelasi aitem total artistik

\begin{tabular}{|c|c|c|}
\hline ID & $\begin{array}{l}\text { Corected item- } \\
\text { total corelations }\end{array}$ & Keterangan \\
\hline SACII_11 & 0,515 & $\begin{array}{l}\text { Aitem valid memiliki daya beda yang baik dan } \\
\text { signifikan }\end{array}$ \\
\hline SACII_12 & 0,486 & $\begin{array}{l}\text { Aitem valid memiliki daya beda yang baik dan } \\
\text { signifikan }\end{array}$ \\
\hline SACII_13 & 0,520 & $\begin{array}{l}\text { Aitem valid memiliki daya beda yang baik dan } \\
\text { signifikan }\end{array}$ \\
\hline SACII_14 & 0,530 & $\begin{array}{l}\text { Aitem valid memiliki daya beda yang baik dan } \\
\text { signifikan }\end{array}$ \\
\hline SACII_15 & 0,585 & Daya beda baik \\
\hline
\end{tabular}


Tabel 6 Korelasi aitem total sosial

\begin{tabular}{|c|c|c|}
\hline ID & $\begin{array}{l}\text { Corected item- } \\
\text { total corelations }\end{array}$ & Keterangan \\
\hline SACII_16 & 0,498 & $\begin{array}{l}\text { Aitem valid memiliki daya beda yang baik dan } \\
\text { signifikan }\end{array}$ \\
\hline SACII_17 & 0,542 & $\begin{array}{l}\text { Aitem valid memiliki daya beda yang baik dan } \\
\text { signifikan }\end{array}$ \\
\hline SACII_18 & 0,519 & $\begin{array}{l}\text { Aitem valid memiliki daya beda yang baik dan } \\
\text { signifikan }\end{array}$ \\
\hline SACII_19 & 0,573 & $\begin{array}{l}\text { Aitem valid memiliki daya beda yang baik dan } \\
\text { signifikan }\end{array}$ \\
\hline SACII_20 & 0,641 & $\begin{array}{l}\text { Aitem valid memiliki daya beda yang baik dan } \\
\text { signifikan }\end{array}$ \\
\hline
\end{tabular}

Tabel 7Korelasi aitem total enterpresing

\begin{tabular}{|c|c|c|}
\hline ID & $\begin{array}{l}\text { Corected item- } \\
\text { total corelations }\end{array}$ & Keterangan \\
\hline SACII_21 & 0,778 & $\begin{array}{l}\text { Aitem valid memiliki daya beda yang baik dan } \\
\text { signifikan }\end{array}$ \\
\hline SACII_22 & 0,768 & $\begin{array}{l}\text { Aitem valid memiliki daya beda yang baik dan } \\
\text { signifikan }\end{array}$ \\
\hline SACII_23 & 0,764 & $\begin{array}{l}\text { Aitem valid memiliki daya beda yang baik dan } \\
\text { signifikan }\end{array}$ \\
\hline SACII_24 & 0,717 & $\begin{array}{l}\text { Aitem valid memiliki daya beda yang baik dan } \\
\text { signifikan }\end{array}$ \\
\hline SACII_25 & 0,555 & $\begin{array}{l}\text { Aitem valid memiliki daya beda yang baik dan } \\
\text { signifikan }\end{array}$ \\
\hline
\end{tabular}

Tabel 8 Korelasi aitem total conventional

\begin{tabular}{lll}
\hline ID & $\begin{array}{l}\text { Corected item- } \\
\text { total corelations }\end{array}$ & Keterangan \\
\hline SACII_26 & 0,728 & $\begin{array}{l}\text { Aitem valid memiliki daya beda yang baik dan } \\
\text { signifikan }\end{array}$ \\
SACII_27 & 0,773 & $\begin{array}{l}\text { Aitem valid memiliki daya beda yang baik dan } \\
\text { signifikan }\end{array}$ \\
SACII_28 & 0,796 & $\begin{array}{l}\text { Aitem valid memiliki daya beda yang baik dan } \\
\text { signifikan } \\
\text { Aitem valid memiliki daya beda yang baik dan } \\
\text { signifikan } \\
\text { Aitem valid memiliki daya beda yang baik dan } \\
\text { signifikan }\end{array}$ \\
SACII29 & 0,728 &
\end{tabular}

Berdasarkan pengujian validitas $\mathrm{p}<0,05$. Hasil ini menunjukkan skor total konvergen dengan menguji korelasi antara perdimensi alat ukur SACII-SR dan Skor total skor total perdimensi alat ukur SACII-SR perdimensi alat ukur O*NET interest profiler dengan $O^{*} N E T$ Interest Profiler didapatkan short form memiliki koefisien korelasi yang hasil dari 0,726 sampai dengan 0,791 dan kuat dan signifikan. 
Tabel 9 Hasil uji korelasi antara SACII-SR dengan O*NET

\begin{tabular}{llll}
\hline Dimensi & Nilai $r$ & Sig & Interpretasi \\
\hline Realistic & 0,740 &, 00 & Kuat \\
Investigative & 0,791 &, 000 & Kuat \\
Artistic & 0,774 &, 000 & Kuat \\
Social & 0,746 &, 000 & Kuat \\
Enterprising & 0,787 &, 000 & Kuat \\
Conventional & 0,726 &, 000 & Kuat \\
\hline
\end{tabular}

Berdasarkan pengujian internal koefesien reliabilitas diatas 0,7. Koefisien consistency dengan teknik Cronbach's alpha reliabilitas menunjukkan bahwa alat ukur didapatkan hasil sebesar 0,777 sampai SACII-SR memiliki reliabilitas yang dapat dengan 0,901 Hal ini menunjukkan enam diterima dan memiliki konsistensi skor antara dimensi alat ukur SACII-SR memiliki nilai aitem sehingga dapat dipercaya.

Tabel 10 Reliabilitas internal consistency

\begin{tabular}{ll}
\hline Dimensi & Koefisien Cronbach's Alpha \\
\hline Realistic & 0,901 \\
Investigative & 0,870 \\
Artistic & 0,759 \\
Social & 0,777 \\
Enterprising & 0,881 \\
Conventional & 0,900 \\
\hline
\end{tabular}

\section{Pembahasan}

Penelitian ini bertujuan untuk menguji validitas dan reliabilitas South African Career Interest Inventory versi bahasa Indonesia .South African Career Interest Inventory digunakan untuk mengukur minat karier seseorang, SACII-SR terdiri dari 30 aitem dengan enam dimensi yaitu Realistic, Investigative, Artistic, social, enterprising dan conventional. SACII-SR menggunakan skala likert dari 1-5. Hasil akhir pengukuran yang dihasilkan SACII-SR yaitu skor total untuk masing-masing dimensi RIASEC.

Menurut Siyoto (2015) sebuah alat ukur yang baik harus memenuhi dua syarat yaitu validitas dan reliabilitas. Sebuah alat ukur dikatakan valid apabila mengukur apa yang hendak diukur. Reliabilitas sebuah alat ukur dilihat dari tinggi rendahnya suatu angka yang disebut koefisien reliabilitas. Aitem yang baik adalah aitem yang mempunyai koefisien reliabilitas lebih dari sama dengan 0,7 .

Peneliti telah melakukan uji validitas dan reliabilitas pada alat ukur SACII-SR. Beberapa tahap analisa data dilakukan oleh peneliti terhadap alat ukur SACII-SR. Pertama, peneliti memaparkan gambaran rata-rata data partisipan berdasarkan data demografis, Kedua, peneliti melakukan uji normalitas untuk melihat distribusi dari data yang telah didapatkan berdistribusi normal atau tidak. Ketiga, peneliti melakukan uji validitas dengan uji validitas tampang 
menggunakan expert review, menghitung item total correlation dan validitas konvergen. Keempat, peneliti melakukan uji reliabilitas menggunakan metode internal consistency.

Pengujian analisa untuk aitem-aitem dari alat ukur SACII-SR dilakukan dengan uji item total correlation. Pengujian item total correlation dilakukan dengan melihat skor corrected item total correlation. Hasil dari pengujian item total correlation pada SACII-SR dari 0,486 sampai dengan 0,805. Hasil dari pengujian item total correlation ini menunjukkan bahwa tiap butir-butir aitem dari SACII-SR dapat dinyatakan valid dan tiap aitemnya mengukur hal yang sama dengan apa yang diukur oleh seluruh aitem pada setiap dimensi. Hal ini sesuai dengan Sugiyono (2017) yang menjelaskan bahwa suatu butir pertanyaan dikatakan valid jika nilai r-hitung yang merupakan nilai dari Corrected item-Total Correlation > 0,30.

Pengujian validitas untuk alat ukur SACII-SR dilakukan dengan metode validitas konvergen. Pengujian validitas konvergen dilakukan dengan menguji koefisien korelasi antara alat ukur SACII-SR dengan $O * N E T$ interest profiler short form. Peneliti mengkorelasikan realistic dari SACII-SR dengan dengan realistic dengan O*NET mendapatkan hasil adanya korelasi yang kuat dan signifikan antara keduanya 0,740, $\rho<0,05$. Korelasi dimensi Investigative SACII-SR dengan O*NET mendapatkan hasil adanya korelasi yang kuat dan signifikan antara keduanya $0,791, \rho<0,05$. Korelasi dimensi artistic SACII-SR dengan O*NET mendapatkan hasil adanya korelasi yang kuat dan signifikan antara keduanya 0,774, $\rho<0,05$. Korelasi dimensi social SACII-SR dengan O*NET mendapatkan hasil adanya korelasi yang kuat dan signifikan antara keduanya 0,746, $\rho<0,05$. Korelasi dimensi enterprising SACII-SR dengan O*NET mendapatkan hasil adanya korelasi yang kuat dan signifikan antara keduanya 0,787, $\rho<$ 0,05 . Korelasi dimensi conventional SACII-
SR dengan $\mathrm{O}^{*} \mathrm{NET}$ mendapatkan hasil adanya korelasi yang kuat dan signifikan antara keduanya 0,726, $\rho<0,05$. Hasil uji korelasi SACII-SR dengan O*NET yang berkorelasi dengan kuat menunjukkan bahwa keduanya mengukur konstruk yang sama yaitu minat karier dalam dimensi RIASEC. Sesuai dengan penelitian sebelumnya di South Africa, validitas dilakukan dengan mengkorelasikan SACII Long form dengan SACIl short form. Koefisien korelasi yang didapatkan sebesar 0,82 sampai 0,92 (Morgan \& Bruin,2019).

Setelah pengujian validitas peneliti melakukan pengujian reliabilitas internal consistency dengan menggunakan rumus Cronbach's Alpha. Hasil Koefisien reliabilitas SACII-SR dari rentang 0,759 sampai dengan $0,901(\mathrm{R}=0,901, \quad I=0,870, \quad A=0,759, S=0,7$ $77, E=0,881, C=0,900)$.Menurut Wels dan Wollack (dalam Azwar,2018) suatu alat tes dapat dinyatakan reliabel jika memiliki koefisien reliabilitas >0,7.berdasarkan koefisien reliabilitas dapat disimpulkan bahwa SACII-SR merupakan alat ukur yang reliabel. Hasil penelitian ini menunjukan SACII-SR mampu mengukur konstruk minat karier RIASEC secara konsisten. Hal ini sesuai dengan penelitian sebelumnya di South Africa yaitu SACII-SR merupakan alat ukur minat karier yang reliabel dengan koefisien reliabilitas antara 0,72 sampai 0,83 (Morgan \& Bruin, 2019). Hasil koefisien reliabilitas dalam penelitian dapat dibandingkan dengan beberapa hasil penelitian alat ukur minat versi pendek lainnya. Contohnya, Dalam ONET $^{*}$ mini interest profiler didapatkan koefisien reliabilitas 0,70 sampai 0,75 (Rounds et al. 2010). . Selain itu, alat ukur minat 18REST (Ambiel,Hauck-Filho,Barros, Martins,Abrahams, \& De Fruyt, 2018) menunjukkan koefisien reliabilitas dari 0,68 sampai 0,81 .

\section{Kesimpulan}

Berdasarkan hasil penelitian dapat disimpulkan bahwa hipotesis penelitian 
diterima, yang berarti South African Career Interest Inventory Short Form dalam versi Bahasa Indonesia merupakan alat ukur yang valid dan reliabel. Pengujian normalitas yang dilakukan menunjukkan data berdistribusi normal berdasarkan hasil skewed dan kurtosis yang juga didukung oleh P-P plot. Hasil perhitungan item total correlation menunjukkan semua item memiliki daya beda yang baik dan valid. Oleh karena itu tidak ada item yang digugurkan.

Hasil uji validitas konvergen SACII-SR dengan ONET* IPSF menunjukkan kedua alat ukur mengukur konstruk yang sama. Diperoleh koefisien korelasi dari rentang 0,726 sampai dengan 0,791 ( $R=0,740, I=0,791, A=0,774$, $S=0,746, E=0,787, C=0,726)$. Hasil reliabilitas menunjukan SACII-SR memiliki reliabel karena pengujian reliabilitas menggunakan internal consistency dengan perhitungan cronbach's alpha diperoleh hasil rentang 0,759 sampai dengan 0,901. Berdasarkan koefisien reliabilitas yang didapatkan, maka dapat disimpulkan bahwa alat tes SACII-SR memiliki reliabilitas yang baik.

Adapun implikasi dalam penelitian ini adalah Penelitian selanjutnya dapat menggunakan alat ukur SACII-SR untuk dianalisa dan diperkenalkan pada dunia pendidikan serta konseling karier di Indonesia dengan aitem yang semakin ringkas dan mudah diaplikasikan sesuai dengan perkembangan alat ukur yang semakin maju.

Pada penelitian selanjutnya diharapkan sampel yang didapatkan berasal dari domisili kota yang beragam. Kedua, penelitian selanjutnya dapat mempertimbangkan penggunaan teknik cluster sampling agar sampel yang digunakan dapat mewakili populasi dan bisa dijadikan norma. Menurut Siyoto (2015) Teknik cluster sampling dipakai untuk menentukan sampel jika sumber data yang akan diteliti sangat luas, seperti penduduk pada suatu negara provinsi atau kabupaten.
Ketiga, penelitian selanjutnya dapat menguji validitas menggunakan metode yang lebih banyak seperti validitas logis dan validitas faktorial. Sesuai dengan Azwar (2019) yang menjelaskan terdapat beberapa prosedur yang dapat digunakan untuk menguji validitas yaitu validitas isi yang terdiri dari tampang dan logis, validitas konstruk yang terdiri multitrait multimethod dan analisa faktorial, dan validitas kriteria yang terdiri dari konkuren dan prediktif. Keempat, penelitian selanjutnya dapat mempertimbangkan melakukan uji validitas menggunakan metode yang lebih kompleks seperti CFA dan model Rasch untuk menguji fungsi aitem. Menurut Morgan dan Bruin (2019) perlu dilakukan validitas struktural SACII-SR untuk menyelidiki fungsi aitem.

\section{Daftar Pustaka}

Alfin, R. (2018). Pengaruh disiplin, motivasi dan kompetensi kerja terhadap kinerja karyawan (studi Kasus pada PT Marinecipta Agung Pasuruan). JAMSWAP, 3(3), 19-31.

Ambiel, R. A. M., Hauck-Filho, N., Barros, L. D. O., Martins, G. H., Abrahams, L., \& De Fruyt, F. (2018). 18REST: A short RIASEC-interest measure for large-scale educational and vocational assessment. Psicologia: Reflexão e Crítica, 31(6), 1-11. https://doi.org/10.1186/s41155-0180086-z.

Ardiyanti \& Alsa (2015). Pelatihan "PLANS" untuk meningkatkan efikasi diri dalam pengambilan keputusan karier. Gadjah Mada Journal of Professional Psychology. 1(1) 1-17.

Akmal, Z. S., Arlinkasari, F., \& Kumalasari, D. (2017). Pengenalan minat sebagai salah satu upaya membantu merencanakan masa depan siswa. Empowering :Jurnal Pengabdian masyarakat, 1, 13-22. doi : http://jurnal.unmuljember.ac.id/index.php/ EMPOWERING/article/view/zak 
Andaridefia, L. (2019). Riset Youthmanual : 92\% Siswa SMA \& SMK bingung mau kerja apa [online]. Diunduh dari https:// kumparan.com/millennial/riset-youthmanual92-persen-siswa-sma-and-smk-bingungmau-bekerja-apa-1reU4BV9dg1/full

Azwar, S. (2019). Reliabilitas dan validitas . Yogyakarta: Pustaka Pelajar.

Cohen \& Swerdlik,. (2009). Psychological Testing and Assessment: An Introduction to Tests and Measurement (7th ed). USA : The Mcgraw-Hill Companies.

Consulting Psychologist Press. (2004). Strong Interest Inventory. Palo Alto, CA: CPP.

Consulting Psychologist Press. (2012). Strong Interest Inventory. Palo Alto, CA: CPP.

Cummings, T.G., \& Worley C.G. (2009). Organization Development \& Change. USA : South- Western Cengage Learning.

Dempster, M. \& Hanna, D. (2015). Research Methods in Psychology for Dummies. Chichester, UK: Wiley.

Field, A. (2017). Discovering statistics using IBM SPSS statistics. North American :Sage.

Goldstein, G., Allen, D., \& Delluca, J. (2019). Handbook of psychological assessment ( $4^{\text {th }}$ edition.). United States : Elsevier.

Hamzah, A. (2019). Kematangan karier teori dan pengukuran. Malang : Literasi Nusantara.

Hansen, J.C., \& Campbell, D.P. (1985). Manual for the SVIB_SCII (4 $\left.4^{\text {th }} \mathrm{Ed}\right)$. Stanford, CA: Stanford University Press.

Holland, J. L. (1971). The Counselor's Guide to the Self Directed Search. Palo Alto, CA: Consulting Psychologist Press.

Holland, J. L. (1979). The Self Directed Search Profesional Manual. Palo Alto, CA: Consulting Psychologist Press.

Holland, J. L. (1985). Making vocational choices: $A$ theory of vocational personalities and work environments (Second ed.). Englewood CliVs, NJ: Prentice-Hall.
Holland, J. L. \& Messer M.A. (2013b). John Holland's SelfDirected Search Profesional Manual. Lutz, FL: Psychological Assesment Resources, Inc.

Johansson, C.B. (1975). Manual of the Career Assesment Inventory. Mineannpolis, MN : National Computer System.

Johansson, C.B. (1986). Career Assesment Inventory : Ehanced Version. Mineannpolis, MN : National Computer System.

Keefe, R. S., Harvey, P. D., Goldberg, T. E., Gold, J. M., Walker, T. M., Kennel, C., \& Hawkins, K. (2008). Norms and standardization of the Brief Assessment of Cognition in Schizophrenia (BACS). Schizophrenia research, 102(1-3), 108-115.

Kennelly, E., Sargent, A., \& Reardon, R. (2018). RIASEC literature from 1953-2016: Bibliographic references to holland's theory, research, and appllications ( Technical Report No. 58). Center for Study of Technology in Counseling and Career Development, 1 , 6-8. doi: https://diginole.lib.fsu.edu/islandora/ object/fsu:543802/datastream/PDF/view

Kuder, G.F. (1948) Kuder Preference RecordPersonal. Oxford : Science Research Associate.

Kumaidi., Farida, R., \& Haq, B. H. A. (2017). Skala minat kejuruan : Strategi mengenali minat vokasi siswa. Proceeding $6^{\text {th }}$ University Research Colloquium 2017 : Seri Humaniora, Sosial, dan Agama, 553562. doi : http://journal.ummgl.ac.id/index. php/urecol/article/view/1444

Leavy, P. (2017). Research Design: Quantitative, qualitative, mixed methods, Narts-based, and community-based participatory research approaches. New York: The Guilford Press.

Morgan, B. \& Bruin, G. P. (2019). Development and evaluation of a short RIASEC career interest inventory. International Journal for Educational and Vocational Guidance, 19, 437-454. doi : https://doi.org/10.1007/ s10775-019-09387-2 
Nasution, S. (2016). Metode research (penelitian ilmiah): usul tesis, desain penelitian, hipotesis, validitas, sampling, populasi, observasi, wawancara, angket. Jakarta: Bumi Aksara.

Pradnyadari, S. D. M. N., \& Herdiyanto, K. Y. (2018). Dinamika perencanaan karir remaja perempuan bali. Jurnal Psikologi Udayana, 5, 251-267. doi : https://ojs. unud.ac.id/index.php/psikologi/article/ download/43247/26273

Price, L.R. (2017). Psychometric Methods Theory. New Jersey : The Guilford Press

Rabie,S. (2017)ATranslationandpsychometric investigation of the south african career interest inventory across gender and race among secondary school learners. Dissertation Presented for the Degree of Doctor of Philosophy ( Psychology). Stellenbosch University. doi : https:// scholar.sun.ac.za/handle/10019.1/102811

Ratri, D. W. (2016). Validasi Holland self directed search (SDS) form CP sebagai alat ukur minat karier. Universitas Gajah Mada. doi : https://www.academia. edu/34601886/VALIDASI_HOLLAND_SELF_ DIRECTED SEARCH_SDS_FORM_CP SEBAGAI_ALAT_UKUR_MINAT_KARIR WIDIASIH_DIANA_RATRI_12_339791_ PPS_2625_PROGRAM_MAGISTER_ PSIKOLOGI_PROFESI_FAKULTAS_ PSIKOLOGI_UNIVERSITAS_GADJAH_ MADA_YOGYAKARTA_

Rounds, J., Su, R., Lewis, P., \& Rivkin, D. (2010). O*NET interest profiler short form psychometrics characteristics : summary. Raleigh, NC : National Center for O*NET Development.

Rothwell, J.W. (1947). A Ranking Method of Assessing Vocational Interest. Melbourne : University of Melbourne.

Setiawati, A. F., Ayriza, Y., Retnowati, E., \& Amelia, N. R. (2017). The response patterns of the career interest intstrument based on Holland's theory. Anima Indonesia Psychological Journal,
32(3),128-147 doi : https://doi.org/10.24123/ aipj.v32i3.628

Sisca. \& Gunawan, W. (2015). Gambaran adaptabilitas karier remaja. Jurnal Psikologi, 11(2) .doi: http://ejournal.uinsuska.ac.id/index.php/psikologi/article/view/1402

Steinberg, L. (2014) Adolescence (10th edition). New York, NY: McGraw-Hill

Süerdem, A. \& Erkök, B. (2016). Assessing the reliability and validity of a shorter version of RIASEC in Turkish. SHS WEB Conferences, 26,8. doi : 10.1051/ shsconf/20162601063

Susantoputri. Kristina, M., \& Gunawan, W. (2014). Hubungan antara efikasi diri karier dengan kematangan karier pada remaja di daerah Kota Tanggerang. Jurnal Psikologi, 10, 1. doi : http://ejournal. uin-suska.ac.id/index.php/psikologi/article/ view/1180/1072

Supraktiknya, A. (2014). Pengukuran psikologi. Yogyakarta : Universitas Sanata Dharma.

Super, D.E. (1975). The psychology of career ; an introduction vocational development. New York : John Wiley \& Sons Inc.

Super, D.E., Thompson, A.S., Lindeman, R.H., Jordan, J.P., \& Myers, R.A. (1981). Career development Inventory : user's manual. Palo Alto, CA : Consulting Psychologists Press.

Siyoto, S., \& Sodik, A. (2015). Dasar metodologi penelitian. Yogyakarta: Literasi Media Publishing .

Student Research Foundation (2018). What Influences Student Career Choices [online]. Diunduh dari www. studentresearchfoundation.org/blog/whatinfluences-student-career-choices/

Sugiyono. (2017). Metode penelitian kuantitatif, kualitatif dan R\&D. Bandung: Alfabeta.

Syamsudin, A., Hakim, L., \& Atmasari, A. (2019). Pengaruh efikasi diri terhadap minat berwirausaha mahasiswa fakultas ekonomi dan bisnis universitas teknologi Sumbawa . Jurnal Psimawa, 2(1), 58-62 
Urbina, S. (2014). Essentials of psychological testing. New Jersey: John Wiley \& Sons, Inc.

Yilmaz, O. (2017). An evidence for validity of Holland's theory of personality types in of RIASEC in Turkish. Psychology Research, 7 (5) 274-273. doi : doi:10.17265/2159$5542 / 2017.05 .002$

Yudiana, W., Reswara, P.I., Wiyono, S. \& Purwono, U. (2019). Padjajaran interest inventory : Evaluation of psychometric properties. Jurnal Psikologi, 46(1), 19-31. doi : 10.22146/jpsi.38684 